УдК 316.46:159.923.3

\title{
ХАРИЗМА В МОРФОЛОГИИ ЛИДЕРСТВА: КОНЦЕПТУАЛИЗАЦИЯ ИДЕИ
}

\author{
Моисеенко Мария Сергеевна, \\ mishutina@tpu.ru \\ Национальный исследовательский Томский политехнический университет, \\ Россия, 634050, г. Томск, пр. Ленина, 30
}

Моисеенко Мария Сергеевна, начальник управления корпоративных и внешних коммуникаций Национального исследовательского Томского политехнического университета.

В статье раскрыты роль и значение авторитета харизмы в морфологии лидерства. Обозначен статус харизмы в совокупности атрибутивных характеристик жизненного мира лидера. Раскрыта роль харит в культуре античности, в греко-иудейской традиции. Обозначена идея специфики социологического дискурса исследования харизматического лидерства в концепции М. Вебера. Проблема харизматического лидерства представлена посредством обращения к конщептуальной интерпретации феноменов власти, авторитета, легитимного господства. Анализируются атрибутивные характеристики харизматического лидерства.

Ключевые слова: Лидер, авторитет, харизма, морфология лидерства, сверхповседневность, эмоциональный интеллект.

\begin{abstract}
Лидерам принадлежит значительная роль в создании устремлений того коллективного сознания, которым является общество. Лидеры могут служить символом нравственного единения общества. Они могут выражать иенности и работать на сплочение общества. Но главное, что они способны постигать, выдвигать иели, заставляюшие людей оторваться от своих мелочных забот, поднять головы, посмотреть выше и дальше конфликтов, раздирающих общество. Лидеры способны объединить усилия многих в достижении иелей, достойных лучших устремлений человека...
\end{abstract}

Дж. Гарднер

Особое место в совокупности атрибутивных характеристик жизненного мира лидера занимает харизма (в греческом языке - оказанная милость, дар). Греко-ивритское основание нам видится в обозначенном термине (древнееврейское «хэсэр» - благодать, греческое «харис» - милость, доброта, радость). Идея сформированности института харизматического лидерства в иррациональной интерпретации принадлежит М.М. Волобуевой [1]. Автор выявляет употребление этого термина в раннем христианстве, при описании тех, кто обладает дарами пасторства и апостольства. В теологии христианства термин «харизма» использовался при упоминании девяти даров святого духа, излитых на апостолов в Иерусалиме, в храме, в праздник пятидесятницы. Однако само понятие «лидерство», в основании которого лежит харизма, возникло значительно раньше: это лидерство главы рода, племени, лидер тотемический, лидер генеалогический (что определялось родством с божеством - египетским фараоном), лидер Откровения (Мухаммед, 
Зороастр), реинкарнационный лидер (Далай Лама), инициальный лидер. Аналитики пишут о явлении альтернативной харизмы в конфессиональном сообществе: это явление, не обусловленное ортодоксальной конфессиональной теорией, имеет иной источник (речь идёт о лидерах мистериальных сообществ, сект, тайных орденов) [1].

Истоки употребления термина можно увидеть в культуре античности, где хариты (от лат. Harity) - дочери Зевса и Геры или океаниды Евриномы. В античной Греции хариты почитались как богини красоты, весёлой, светской, праздничной жизни. У Гектора это Ефросина (праздничное веселье), Аглая (праздничный блеск), Талия (цветущее счастье). На Олимпе их друзья - Музы, богини пения. Афродита Пейто (богиня убеждения) и наделённый умением красиво говорить Гермес всегда появляются в сопровождении харит, поскольку лишь с помощью красоты и привлекательности харит Афродита и Гермес способны пленять и оказывать действие. Первоначально хариты считались почитаемыми у минийцев в Орхомене, было введено служение им (при Этеонле). Из Орхомена служение харитам перешло на ряд иных государств Греции. Для спартанцев объектом почитания были Клета и Фаэнна (звук и свет), жители Афин поклонялись Ауксо, покровительнице роста, и Гегемоне (предводительнице). Хариты общительны, их изображают всегда втроём. Милые, цветущие, девственные хариты изображаются с музыкальными инструментами, миртами, розами, с игральными картами.

Позднее появившийся термин «харизма» означал ту степень особого дара, одарённости, благодаря которому человек совершил, казалось бы, невозможное. Ветхий Завет наделяет термин «харизма» религиозным смыслом: это божественный дар свыше, им наделяются те, кто призван на царство, пророчество, служение, в то время как в Новом Завете под «харизмой» понимается благодать («по данный нам благодати имеем различные дарования» [2, Послание к Римлянам, 12 глава, стих 6]; «служите друг другу каждый тем даром, какой получил» [2, 1-е послание Петра, 4 глава, стих 10]).

В средние века формируется теологическая интерпретация понятия «харизмы»это ниспосланные Святым Духом дары: дары откровения (мудрость, знания, способность различать духов); дары силы, в числе которых вера в чудеса и пророчества, исцеление; дары речи.

В науке термин «харизма» появился благодаря работам М. Вебера, Э. Трёльча, Г. Лебона, Г. Тарда, 3. Фрейда, К.Г. Юнга, Э. Фромма, Т. Адорно, Э. Эриксона, С. Московичи, Д. Ранкура-Лафернера, Г. Лассуэлла. Мы полагаем, что масштабный подход к феномену лидерства и анализ многих атрибутивных характеристик его феномена жизненного мира представил впервые М. Вебер, сделав акцент на социологическом дискурсе явления харизматического лидерства. Прежде чем это будет рассмотрено, обозначим то особое, что определяет природу лидерства в целом, не обращаясь к специфике концептуальных интерпретаций. Термином «лидер» (от англ. leader - ведущий) обозначен авторитетный представитель сообщества, группы, организации, обладающий масштабным влиянием; именно степень влияния позволяет лидеру играть существенную роль в совершающихся процессах и ситуациях, позволяет регулировать отношения, воздействовать на членов сообщества с целью интеграции реальности и удовлетворения интересов сообщества. Развёрнутая характеристика анализируемого М. Вебером феномена лидерства строится на максимально разнообразном личностном опыте. Проблема харизматического лидерства представлена посредством обращения концептуальной интерпретации таких феноменов, как власть, авторитет и господство. В качестве дискурса, анализа выступает социологический дискурс.

Отметим, что именно социологический подход позволил автору представить феномен природы власти в её высшем иерархическом воплощении. Одной из работ, в которых 
тема рациональности представлена как тема исторической судьбы западного общества, является написанная в первое десятилетие (1904-1905) «Протестантская этика и дух капитализма» [3]. Социальное действие интерпретировано как исходная, элементарная единица социологического анализа; социальное действие включает в себя осмысленность, субъективную мотивацию и одновременно «ориентацию на других», что делает его социально значимым. Субъектом социального действия становится индивид. Что же касается типологии социального действия, она в концептуальном изложении М. Вебера такова:

- целенаправленное действие (индивид определяет цель и совокупность тех средств, с помощью которых цель достигается; успех определяет правильность избираемых целей); ностей);

- ценностно-рациональное действие (в основание его положена совокупность цен-

- эффективное действие (его определяют эмоции действующего субъекта, состояния аффектов);

- традиционное действие.

Именно разработанная М. Вебером типология, изложенная выше, определяет тип легитимности господства, власти. Автор исходит из постулата - господство рационального является характерной особенностью, атрибутивной характеристикой современного общества. В основание легального типа господства заложено действие целенаправленного типа. Ему присущи начала правового характера, а мотивом признания власти является интерес («Интерес как закон определяет характер действий» (К. Маркс)), в то время как харизматическое господство базируется на эффективности типа социального действия. Атрибутивные характеристики лидера в концептуальном изложении М. Вебера представлены страстью (проявляющейся в самоотдаче), чувством ответственности, умением дать оценку тому действию, которое лидер должен совершить. Именно атрибутивные характеристики лидера являются основанием предложенной М. Вебером типологии лидерства: традиционное лидерство, авторитет которого строится на традициях; традиционно-легальное лидерство, воплощенное в деятельность субъектов, реализующих властные полномочия, которые получены через избрание; харизматическое лидерство, в основании которого «харизма». При этом под «харизмой» понимается «качество личности, признаваемое необычным, благодаря которому она оценивается как одарённая сверхъестественными, сверхчеловеческими или по меньшей мере специфически особыми силами и свойствами, недоступными другим. Она рассматривается как посланная богом или как образец [4].

В отечественной литературе существует точка зрения [1], в соответствии с которой лидерство охарактеризовано М. Вебером с помощью идеальных типов роли законодателя, но всеобщая теория лидерства не стала результатом исследований выдающегося аналитика. Предметом анализа для М. Вебера явилась схема легитимизации власти, анализ проявлений коммуникаций в отношениях «общество-лидер». Мы согласны с позицией автора в той части, где автор сопоставляет варианты (формы правления), утверждая: «... При традиционной форме правления устанавливается внутрисоциальная связь естественного или «традиционного» характера. В варианте «законно-рационального правления» общественный контакт основывается на признании справедливости правления» [4, с. 71]. Харизматический лидер, по мнению М. Вебера, базируется на некоей иррациональной связи лидера и «группы». 
По сути своей и природе харизматический лидер имеет возможность осуществлять власть именно и только потому, что абсолютно верит в свою избранность, которая характерна для него. М. Вебер пишет о религиозных основаниях харизматического лидерства. Выше отмечалась считающаяся обязательной иррациональная связь лидера и ведомых, она основана на сверхчеловеческих иррациональных свойствах. Примечательно, что харизматическое господство для М. Вебера - господство сверхповседневное. Автор связывает его со сверхповседневными свойствами личности лидера и в этом смысле противопоставляет их повседневным видам господства - рациональному и традиционному [4].

Мы считаем это верным, т. к. именно в этом случае «харизма» означает то сверхповседневное (auseralltaglich) качество личности, благодаря которому личность характеризуется как вождь (Führer). При этом М. Вебером отмечено, что безразлично, как данное качество могло бы быть оценено «объективно»; «всё дело заключается в том, как это качество фактически оценивается теми, над кем осуществляется харизматическое господство (charismatisch Beferrschten), сторонниками» [5, с. 20].

Итак, интерес М. Вебера к сверхчеловеческим характеристикам лидеров-вождей, сосуществующий с интересом к рациональной природе власти, утверждение идеи полностью иррационального проявления харизматического лидерства, - то основное, на чём базируется версия харизматического лидерства в концептуальном изложении М. Вебера, то главное, что вызвало исследовательский интерес к его идее у 3. Фрейда, К.Г. Юнга, Т. Адорно, Э. Фромма, С. Московичи, Д. Ранкура-Лафернера, Ж. Блонделя, Г. Лассуэлла и яростные неприятие этой идеи А. Швейцером, А. Уилнером, К. Фридрихом.

Иррациональная связь лидера и ведомых, основанная на сверхчеловеческих, иррационально проявляемых отношениях и свойствах, сосуществует в феномене харизматического лидера с тем, что в аналитической литературе называется эмоциональным интеллектом. На наш взгляд, без него нет харизматического лидерства. Эмоциональный интеллект среди качеств, обуславливающих эффективность масштаба влияния способностей харизматического лидера, занимает особое место. На страницах ведущего мирового делового журнала Harward Business Review в серии «Harward Business Review. Десять лучших статей» феномен эмоционального интеллекта, его природы и роли в отношениях лидерства анализируется Д. Гоулманом. Автор характеризует эмоциональный интеллект через способность к совместной работе и умение добиваться результативности в преобразованиях. В совокупности составляющих эмоционального интеллекта особую роль играют:

- самосознание, выражаемое через способность определять свои ценности и мотивы, достоинства и слабые стороны;

- самоконтроль, заключённый в способности контролировать и придавать плодотворную ориентацию сфере импульсов и эмоций;

- мотивация, выраженная в способности работать ради процесса;

- эмпатия, выраженная в процессах принятия сложных решений, способность понимать эмоциональное состояние других, умение вести себя, учитывая эмоциональное состояние других;

- социальные навыки, выражаемые в умении управлять отношениями, налаживать взаимодействие.

Как утверждает Д. Гоулман, успешность харизматического лидера определяет его интеллект, когнитивные возможности. Однако попытка выявления соотношения специальных знаний и чисто умственных способностей и эмоционального интеллекта привела 
Д. Гоулмана к ошеломляющему выводу - значение эмоционального интеллекта (независимо от уровня управления) вдвое выше значения всего того, что определяет высокую результативность действий харизматического лидера: « ... мой анализ показал... чем более высокий уровень управления рассматривался, тем более существенную роль играли способности, связанные с эмоциональным интеллектом, тогда как различия в функциональных навыках особого значения уже не имели, ... чем выше ранг корифеев управления, тем больше навыков эмоционального интеллекта было заложено в фундамент их успеха» $[6$, с. 10$]$.

В заключение обозначим двойную роль эффективного лидера: аналитики обозначили эти роли как архитектурную и харизматическую. И если, выполняя архитектурную роль, лидер ориентирован на такие вопросы, как поощрение, то, выполняя роль харизматическую, лидер обращён к стратегии, определяющей будущее. М. Кетс де Врис в «Мистике лидерства» [7] обращается к тезису о том, что настоящий лидер невозможен без выполнения этих ролей. Архитектурную роль нельзя отождествлять с менеджментом. В этой роли и через эту роль лидер следует тем правилам, которые вменяют ему функцию провидца, присущую наделённому фантазией лидеру.

Возникает вопрос: возможно ли увидеть в харизме лидера обязательные для лидера этого типа составляющие? Мы считаем возможным утвердительный ответ. Назовём некоторые наиболее важные составляющие: решимость, обусловленная желанием бросить вызов в реальной ситуации, выразив надежду на новое; сдержанность, выраженная в умении ждать (Махатма Ганди, заявивший в нужный момент о «борьбе» satyagraha (борьба воинствующего ненасилия)); владение силой игры в Давида и Голиафа, драматизация риска; харизматический лидер превосходно манипулирует символами, часто прибегает к театрализации, обращается к символизму в речи ( У. Черчилль: «Я могу предложить только кровь, тяжёлый труд, и пот»; Ф. Рузвельт: «Нам стоит бояться только страха»); умение создавать приводящие к успеху альянсы.

Также приведём эмоциональные и драматические стороны в лидерстве, принадлежащие Шекспиру, - Генрих V перед сражением под Азенкуром, где 25 октября 1415 года тяжёлая кавалерия французов окружила обессилевшее войско Генриха $\mathrm{V}$, вдохновляет солдат в канун решающей битвы в столетней войне. Он выразил надежду и веру в своих солдат и подаёт пример мужества:

«Тот, кто сегодня кровь со мной прольёт, мне станет братом: как бы ни был низок; Его облагородит этот день;

И проклянут свою судьбу дворяне, что в этот день не с нами, а в кровати;

Язык прикусят, лишь заговорят;

Соратник наш в Криспианов день».

Король вдохновляет солдат, обнадеживает их, поощряя преданность и риск, назвав солдат счастливчиками: за три часа сражение стало катастрофой для 30 тысяч французов и превратило в счастливчиков 6 тысяч солдат Генриха V.

Харизматический лидер - провидец и пророк, делающий провидческие заявления. Но, как иногда случается, провидец может ошибаться. Дж. Акерс, будучи гендиректором УВМ, полагал, что будущее - за универсальными компьютерами. Он совершил ошибку, отказавшись сделать ставку на более быстрый компьютер. Работы лишились 70 тысяч служащих УВМ. Спасение гиганта обеспечил Луис Терстнер - лидер харизматического типа в деловом мире цифрового века. 


\section{СПИСОК ЛИТЕРАТУРЫ}

1. Волобуева М.М. Философия харизматического лидерства и её имплицированность в поле гуманитарного знания. URL: https://cyberleninka.ru/article/n/filosofiya-harizmaticheskogo-liderstva-i-eeimplitsirovannost-v-pole-gumanitarnogo-znaniya (дата обращения 04.02.2021).

2. Новый Завет. URL: https://planeta.one/bible/n.htm (дата обращения 04.02.2021).

3. Вебер М. Протестантская этика и дух капитализма. URL: http://tower-libertas.ru/wpcontent/uploads/2013/10/Max_Veber_-_Protestantskaya_etika_i_dukh_kapital.pdf (дата обращения 04.02.2021).

4. Вебер М. Харизматическое господство. URL: https://www.gumer.info/bibliotek_Buks/Sociolog/ Article/Veb_HarGosp.php (дата обращения 04.02.2021).

5. Вебер М. Типы господства // Личность. Культура. Общество. - 2008. - Т. 10. - Вып. 3-4 (42-43). C. 20-31.

6. Эмоциональный интеллект. - М.: Альпина Паблишер, 2016. - 224 с.

7. Кетс де Врис М. Мистика лидерства. Развитие эмоционального интеллекта. - М: Альпина Бизнес Букс, 2007. - $276 \mathrm{c}$. 
UDC 316.46:159.923.3

\title{
CHARISM IN THE MORPHOLOGY OF LEADERSHIP: CONCEPTUALIZATION OF THE IDEA
}

\author{
Maria S. Moiseenko, \\ mishutina@tpu.ru \\ National Research Tomsk Polytechnic University, \\ 30, Lenin Avenue, 634050, Tomsk
}

Maria S. Moiseenko, Head of Corporate and External Communications, National Research Tomsk Polytechnic University.

The article reveals the role and significance of the authority of charisma in the morphology of leadership. The status of charisma is indicated in the aggregate of the attributive characteristics of the leader's life world. The role of harit in the culture of antiquity, in the Greek-Jewish tradition is revealed. The idea of the specificity of the sociological discourse of the study of charismatic leadership in the concept of M. Weber is outlined. The problem of charismatic leadership is presented through an appeal to a conceptual interpretation of the phenomena of power, authority, and legitimate domination. The attributive characteristics of charismatic leadership are analyzed.

Key words: Leader, authority, charisma, leadership morphology, everyday life, emotional intelligence.

\section{REFERENCES}

1. Volobueva M.M. Filosofiya kharizmaticheskogo liderstva i ee implitsirovannost v pole gumanitarnogo znaniya [Philosophy of charismatic leadership and its implication in the field of humanitarian knowledge]. Available at: https://cyberleninka.ru/article/n/filosofiya-harizmaticheskogo-liderstva-i-ee-implitsirovannostv-pole-gumanitarnogo-znaniya (accessed 4 February 2021).

2. Novy Zavet [New Testament]. Available at: https://planeta.one/bible/n.htm (accessed 4 February 2021).

3. Veber M. Protestantskaya etika i dukh kapitalizma [Protestant ethics and the spirit of capitalism]. Available at: http://tower-libertas.ru/wp-content/uploads/2013/10/Max_Veber_-_Protestantskaya_etika_i_dukh_ kapital.pdf (accessed 4 February 2021).

4. Veber M. Kharizmaticheskoe gospodstvo [Charismatic domination]. Available at: https://www.gumer.info/bibliotek_Buks/Sociolog/Article/Veb_HarGosp.php (accessed 4 February 2021).

5. Veber M. Tipy gospodstva [Types of domination]. Lichnost. Kultura. Obshchestvo, 2008, Vol. 10, Iss. 3-4 (42-43), pp. 20-31.

6. Emotsionalny intellekt [Emotional intelligence]. Moscow, Alpina Publ., 2016. 224 p.

7. Kets de Vris M. Mistika liderstva. Razvitie emotsionalnogo intellekta [Leadership mysticism. Development of emotional intelligence]. Moscow, Alpina Biznes Buks Publ., 2007. 276 p.

Received: 20 March 2021. 